Article

\section{Unusual vertical distribution of zooplankton and fish in the pelagic zone of Lake Sevan during summer stratification}

\author{
Mikhail I. Malin*®, Svetlana M. Zhdanova ${ }^{\odot}$, Dmitriy B. \\ Kosolapov ${ }^{\circledR}$, Inga P. Malina ${ }^{\circledR}$, Natalya G. Kosolapova ${ }^{\circledR}$, \\ Rimma Z. Sabitova ${ }^{\circledR}$, Alexandr V. Krylov
}

I.D. Papanin Institute for Biology of Inland Waters, Russian Academy of Sciences, Borok 109, Nekouz District, Yaroslavl Region, 152742 Russia

*mishuk@ibiw.ru

Received: 12.03 .2021

Revised: 19.04.2021

Accepted: 19.05.2021

Published online: 13.08.2021

DOI: $10.23859 /$ estr-210312

UDC 574.583:591(282.247.441.821)

Translated by D.M. Martynova

\begin{abstract}
Previous studies in Lake Sevan during summer stratification have shown that the highest zooplankton abundance and biomass was found at the lower boundary of the epilimnion. At the same time, whitefish (Coregonus lavaretus), being main planktivorous species in the lake, preferred the hypolimnion, but was leaving this layer if dissolved oxygen concentrations decreased to $1-5 \mathrm{mg} / \mathrm{L}$. The study was conducted in Bolshoy Sevan (the southern part of Lake Sevan) on July 29-30, 2019. The vertical profiles of water temperature and dissolved oxygen concentration, as well as distribution of major taxonomic groups of aquatic organisms were assessed four times a day: in the dark (night time), in the light (day time), and in twilight (morning and evening). Fish population density was assessed using a "Simrad EK80" echosounder. Vertical distribution of zooplankton and fish observed within the study period did not correspond to that described earlier. Maximal zooplankton biomass during the study was recorded in the hypolimnion, and minimal biomass, in the epilimnion. Most of fish (89-100\%) located in the metalimnion. At night, about $10 \%$ of the fish population descended to the hypolimnion, despite the low dissolved oxygen concentrations found there $(3.0-3.1 \mathrm{mg} / \mathrm{L})$. At dawn, about $7 \%$ of the fish ascended to the epilimnion, reaching a $7-\mathrm{m}$ depth, where the water temperature was $20.8^{\circ} \mathrm{C}$. The water temperature range preferred by most fish individuals varied during the observation period and did not correspond to previously reported ranges.
\end{abstract}

Keywords: bacterioplankton, heterotrophic nanoflagellates, whitefish, Coregonus lavaretus, epilimnion, metalimnion, hypolimnion, migration. 


\section{Introduction}

The study of the vertical distribution of biota in a stratified water body provides the researcher with unique material, since the distribution pattern obtained is a result of interactions of aquatic organisms in pronounced heterogeneous environment. Meantime, the spatial maxima of abundance of particular groups of organisms are the indicators of the optimal combination of biotic and abiotic factors. In some cases, unusual pattern forms, which differs much from well-known regularities; this makes it possible to re-evaluate the role of a factor or a complex of factors that have preconditioned such a phenomenon.

Historically, in a stratified Lake Sevan, the highest quantitative indicators of zooplankton were recorded in the epilimnion, in particular, along its lower margin (Krylov etal., 2010, 2016; Nikogosyan, 1985; Simonyan, 1991). In addition, general regularities of the vertical distribution of fish are known for water bodies of similar type; the pelagic species of the Arctic origin attract here special attention. Facing with stratification, they tend to occupy water layer(s), where the temperature conditions are optimal for their state; the latter are most often observed below the thermocline (Poddubny and Malinin, 1988). Main planktivorous species inhabiting Lake Sevan, Coregonus lavaretus (Linnaeus, 1758), prefers quite low water temperatures in summer: 4-9 ${ }^{\circ} \mathrm{C}$ in the northern-western part of Lake Sevan (Maly (Small) Sevan) and $5-7{ }^{\circ} \mathrm{C}$ in its southern part (Bolshoy (Big) Sevan) (Malinin et al., 1984).

At the same time, attention must be paid to the cases of disbalance of the known regularities of the vertical distribution of aquatic organisms. This is especially true in recent years, characterized by high air temperatures, contributing to changing the temperature and oxygen regimes of deep-water lakes (Helland et al., 2007; Razlutskij et al., 2018). The last affects the state of fish species of the Arctic complex, their distribution pattern, and the density of schools (Krivopuskova et al., 2014; Krivopuskova and Sokolov, 2018). In the 1980s, the distribution of whitefish in Lake Sevan depended on the distribution of dissolved oxygen: as the last decreased down to $1-5 \mathrm{mg} / \mathrm{L}$ in the hypolimnion, whitefish left this zone (Poddubny and Malinin, 1988). A change in the population density of plankton-feeding fish causes a transformation of the species composition and quantitative indicators of planktonic invertebrates. This is evidenced by a number of alpine lakes studied, where various species of trout were acclimatized for recreational purposes; as a result, large species of invertebrates, in particular, representatives of the genus Daphnia, disappeared due to their consuming by fish (Fitzmaurice, 1979; Galbraith, 1967; Gliwicz et al., 2000). During the study of Lake Sevan in 20142017 , it was found that as the number of whitefish increased, the abundance and biomass of planktonic crustaceans decreased, mostly due to decreasing share of the large species Daphnia (Ctenodaphnia) magna Straus, 1820 (Krylov etal., 2019a, b). Alongside with a significant increase in fish population density in 2018, D. magna disappeared from the zooplankton community, but the total abundance and biomass of planktonic invertebrates increased, mostly due to other Cladocera, D. (Daphnia) hyalina Leydig.,1860 (Krylov et al., 2021). The distribution of whitefish is the main reason for the uncharacteristic transformation of planktonic invertebrate communities due to the disappearance of $D$. magna, i.e. due to the depletion of the food supply in the water column. Altogether, these resulted in maximum fish density at greater depths than observed in previous years, where temperature and trophic conditions were optimally balanced. At the same time, the food spectrum of whitefish changed, and benthic invertebrates, in particular, amphipods (representatives of the family Gammaridae), had a significant proportion, while earlier it was $D$. magna. However, here we do not analyze the vertical distribution of zooplankton, which makes these assumptions less convincing.

In addition, it is important to take into account diurnal changes in the vertical distribution of zooplankton. Most of the results obtained over more than a century of studies of diurnal vertical migrations (DVM) indicate the following pattern: the descent of zooplankton into the deep layers at dawn and rise to the surface in the evening (Kiselev, 1980; Rudyakov, 1986). DVM of zooplankton are highly variable and complex behavioral phenomenon that obviously cannot be explained by a single factor. Most often, DVM are considered as a result of the complex influence of a number of both abiotic (vertical temperature gradients, ultraviolet radiation, chemical composition of water) and biotic (predation, competition, vertical distribution of food) factors (Brooks and Dodson, 1965; De Meester et al., 1999; Gerritsen, 1982; Han and Straskraba, 1998; Lampert, 1989; Lampert et al., 2003; Larsson and Dodson, 1993; Loose and Dawidowicz, 1994; Ohman et al., 1983; Rhode et al., 2001; Ringelberg, 2010; Shapiro and Wright, 1984; Sih et al., 2000; Spaak and Hoekstra, 1997; Tartarotti et al., 1999; Williamson et al., 2011). It is also necessary to consider separately the features of the vertical distribution of plankton, which are the result of DVM (i.e., active movement up or down), and the distribution patterns formed under other factors (passive transfer with water masses (including horizontal transport), consumption by plankton-feeding species, etc.).

The study aims to analyze the relationship between the diurnal dynamics of the vertical distribution of zooplankton and the planktivorous fish Coregonus lavaretus in the pelagic zone of Lake Sevan during water stratification in summer. 


\section{Materials and methods}

Lake Sevan (N $40^{\circ} 18.6^{\prime} \mathrm{E} 45^{\circ} 20.9^{\prime}$ ) is located in the center of the eastern part of the Republic of Armenia at an altitude of $1,900 \mathrm{~m}$ above sea level. The lake consists of two parts: Maly (Small) Sevan (area $\sim 322 \mathrm{~km}^{2}$, max. depth $82 \mathrm{~m}$ ) and Bolshoy (Big) Sevan (area $\sim 928 \mathrm{~km}^{2}$, max. depth $36 \mathrm{~m}$ ), which are connected by a $5.5-\mathrm{km}$ wide strait (Asatryan et al., 2016).

The sampling was carried out in Bolshoy Sevan on July 29-30, 2019, onboard the R/V "Gidrolog" (site $\mathrm{N} 40^{\circ} 24.1^{\prime} \mathrm{E} 45^{\circ} 27.3^{\prime}$ ), where preliminary hydroacoustic survey revealed pelagic schools of fish identified as whitefish. The material was collected at different periods of the day, differing in light conditions: in the evening twilight (at sunset), in the dark (at night), in the morning at twilight (at dawn), and in the daytime (maximum illumination). The sampling site depth was 24-26 m, this difference was due to the bottom relief (slope).

The water temperature and the content of dissolved oxygen were determined every $1-\mathrm{m}$ lag with a multiparameter probe "YSI ProPlus" before taking biological samples in order to determine the boundaries of epilimnion (EL), metalimnion (ML), and hypolimnion $(\mathrm{HL})$ in the water column. Bacterioplankton (BP), heterotrophic nanoflagellates (HNF), and zooplankton (ZP) were collected every $1 \mathrm{~m}$ with a Molchanov's 4-L water sampler; the samples from EL, ML, and HL were pooled as integral samples for each layer.

In order to quantify BP and HNF, integral water samples from $E L, M L$, and $H L$ were fixed immediately after sampling with formalin to a final concentration of $1 \%$; the formalin solution was pre-filtered through a membrane filter (0.2- $\mu \mathrm{m}$ pore diameter). The samples were stored in the dark at $4{ }^{\circ} \mathrm{C}$ and processed in the laboratory for a month. The abundance and size of $\mathrm{BP}$ and $\mathrm{HNF}$ were determined by epifluorescence microscopy using DAPI and primulin fluorochromes, respectively (Caron, 1983; Porter and Feig, 1980).

The water samples were filtered through a plankton net (64- $\mu \mathrm{m}$ mesh size) to collect zooplankton, and residuals were fixed with $4 \%$ formalin. Sample processing was carried out according to the standard technique (Rivier, 1975), the biomass was determined taking into account the size of the organisms (Balushkina and Vinberg, 1979). The number of zooplankton species per sample, abundance, biomass, proportion of taxonomic groups, average individual mass of certain organisms (AIM) dominant species and their similarity were assessed; similarity was determined by the Shorygin index (Vainshtein, 1976).

The vertical distribution of fish was estimated by the hydroacoustic method (Simmonds and MacLennan, 2005) with a "Simrad EK80" echo sounder with a dual-frequency antenna ES38-18/200-18C (split beam at $38 \mathrm{kHz}$, single beam at $200 \mathrm{kHz}, 18^{\circ}$ beamwidth at both frequencies), the antenna was set at 1-m depth from the water surface. The survey was performed during the approach of the vessel to the sampling site. The distribution of fish was analyzed using the "Echoview 10" software by echo counting in the depth range from $2.5 \mathrm{~m}$ down to the bottom.

\section{Results}

The water temperature in the EL was $6.1-10.0^{\circ} \mathrm{C}$ higher than in the $\mathrm{ML}$ and by $13.1-14.1{ }^{\circ} \mathrm{C}$ higher than in the HL (Fig. 1). During the day, it changed by $0.3-0.7^{\circ} \mathrm{C}$ in $\mathrm{EL}$, by $0.2-3.5^{\circ} \mathrm{C}$ in $\mathrm{ML}$, the maximum values were recorded at sunset and at night. In the $\mathrm{HL}$, the water temperature fluctuated by $0.1-0.8{ }^{\circ} \mathrm{C}$ with the highest value registered at dawn. The minimum concentration of dissolved oxygen was found in $\mathrm{HL}$, it was higher by $1.1-2.8 \mathrm{mg} / \mathrm{L}$ in $\mathrm{ML}$, and by another $1.5-3.5 \mathrm{mg} / \mathrm{L}$ in EL (Fig. 1). During the day, its concentration varied by $0.1-0.2 \mathrm{mg} / \mathrm{L}$ in EL, by 0.9 $1.9 \mathrm{mg} / \mathrm{L}$ in $\mathrm{ML}$, and by $0.3-0.4 \mathrm{mg} / \mathrm{L}$ in $\mathrm{HL}$; the maximum values were recorded at sunset and at night.

The position of the conditional boundary between $\mathrm{EL}$ and $\mathrm{ML}$ during the day changed by $2-3 \mathrm{~m}$ vertically, while the boundary between $\mathrm{ML}$ and $\mathrm{HL}$ was more stable and remained at a depth of 22-23 m (Fig. 1). In EL and ML, a decrease in water temperature was observed, most noticeable in $\mathrm{ML}$, where the oxygen concentration also decreased. The dynamics of these characteristics has no daily cyclicity; it cannot be explained by the cooling of the water surface at night. This observation evidences indirectly on the presence of horizontal transfer of water masses (currents), which is most intense in the ML.

In $\mathrm{EL}$, the minimum number of $\mathrm{BP}$ was found at dawn, in $\mathrm{ML}$, at night and at dawn, in $\mathrm{HL}$, during the day and at night; its increase in the entire water column was observed at sunset (Table 1). The cell volume and bacterial biomass in all water layers reached a minimum at night, while the maximum in $\mathrm{EL}$ and $\mathrm{ML}$ was noted during the day, and in $\mathrm{HL}$, at dusk and dawn.

The maximum quantitative indicators of HNF in $E L$ and $M L$ were recorded at sunset and at night, in $\mathrm{HL}$, at night and during the day (Table 1). Small flagellates (size $\geq 5 \mu \mathrm{m}$ ) made most of the population at that time. The minimum abundance and biomass of HNF in EL was found at dawn, in ML, during daytime; in $\mathrm{HL}$, the greatest decrease in abundance was observed in the daytime, in biomass, at dawn. A decrease in the volume of flagellate cells in EL was recorded during the day, in ML, during the day and at night, in $\mathrm{HL}$, at dawn. As a rule, at this time, the maximum share of small-sized forms $(<5 \mu \mathrm{m})$ in the total abundance and biomass of HNF was observed.

Zooplankton was presented by seven species of Rotifera (Euchlanis dilatata Ehrenberg, 1832; E. lyra Hudson, 1886; Filinia terminalis (Plate, 1886); Hexarthra mira (Hudson, 1871); Keratella quadrata (Müller, 1786); Polyarthra longiremis Carlin, 1943; 
Table 1. Abundance $(N)$, volume $(V)$, and biomass $(B)$ of bacterioplankton and heterotrophic nanoflagellates.

\begin{tabular}{|c|c|c|c|c|c|c|c|c|c|c|}
\hline \multirow{3}{*}{$\begin{array}{l}\text { Light } \\
\text { conditions }\end{array}$} & \multicolumn{3}{|c|}{ Bacterioplankton } & \multicolumn{7}{|c|}{ Heterotrophic nanoflagellates } \\
\hline & \multirow{2}{*}{$\begin{array}{c}N \\
10^{3} \mathrm{cells} / \\
\mathrm{mL}\end{array}$} & \multirow{2}{*}{$\begin{array}{c}V \\
\mu m^{3}\end{array}$} & \multirow{2}{*}{$\begin{array}{c}B, \\
\mathrm{mg} / \mathrm{m}^{3}\end{array}$} & \multirow{2}{*}{$\begin{array}{c}N, \\
10^{3} \text { cells/ } \\
\mathrm{mL}\end{array}$} & \multirow{2}{*}{$V, \mu m^{3}$} & \multirow{2}{*}{$\begin{array}{c}B, \\
\mathrm{mg} / \mathrm{m}^{3}\end{array}$} & \multicolumn{2}{|c|}{$<5 \mu \mathrm{m}$} & \multicolumn{2}{|c|}{$\geq 5 \mu \mathrm{m}$} \\
\hline & & & & & & & $N, \%$ & $B, \%$ & $N, \%$ & $B, \%$ \\
\hline \multicolumn{11}{|c|}{ Epilimnion } \\
\hline Dusk & 5341 & 0.15 & 775 & 961 & 95.1 & 91.4 & 33.3 & 16.9 & 66.7 & 83.1 \\
\hline Night & 5027 & 0.12 & 624 & 1068 & 61.9 & 66.1 & 30.0 & 17.4 & 70.0 & 82.6 \\
\hline Dawn & 4595 & 0.17 & 786 & 420 & 63.0 & 26.5 & 50.0 & 16.8 & 50.0 & 83.2 \\
\hline Daytime & 5027 & 0.28 & 1389 & 961 & 51.5 & 49.5 & 66.7 & 39.0 & 33.3 & 61.1 \\
\hline \multicolumn{11}{|c|}{ Metalimnion } \\
\hline Dusk & 5341 & 0.14 & 751 & 1410 & 104.2 & 146.8 & 27.3 & 13.3 & 72.7 & 86.7 \\
\hline Night & 4280 & 0.14 & 605 & 1495 & 51.4 & 76.9 & 78.6 & 48.8 & 21.4 & 51.2 \\
\hline Dawn & 4241 & 0.18 & 774 & 1175 & 62.3 & 73.2 & 63.6 & 25.7 & 36.4 & 74.3 \\
\hline Daytime & 5184 & 0.20 & 1022 & 961 & 57.6 & 55.4 & 55.6 & 41.6 & 44.4 & 58.4 \\
\hline \multicolumn{11}{|c|}{ Hypolimnion } \\
\hline Dusk & 8090 & 0.22 & 1778 & 534 & 58.9 & 31.4 & 60.0 & 60.1 & 40.0 & 39.9 \\
\hline Night & 5851 & 0.12 & 731 & 748 & 66.0 & 49.3 & 57.1 & 34.4 & 42.9 & 65.6 \\
\hline Dawn & 6676 & 0.24 & 1624 & 540 & 43.9 & 23.7 & 67.8 & 51.9 & 17.0 & 32.9 \\
\hline Daytime & 5144 & 0.19 & 963 & 427 & 122.5 & 52.3 & 0.0 & 0.0 & 100.0 & 100.0 \\
\hline
\end{tabular}

A

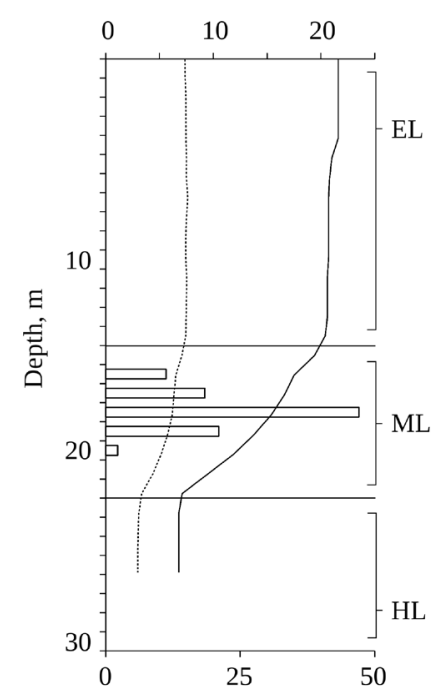

B

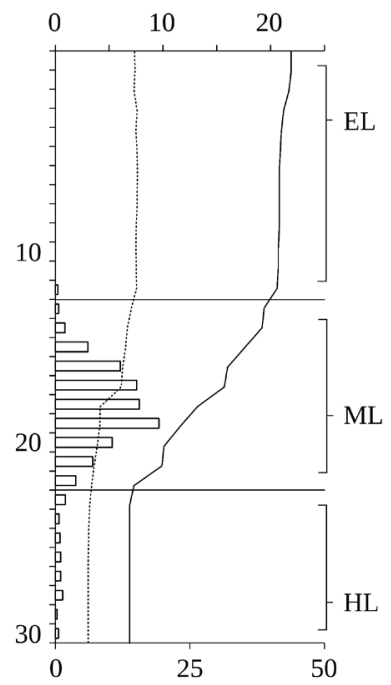

C

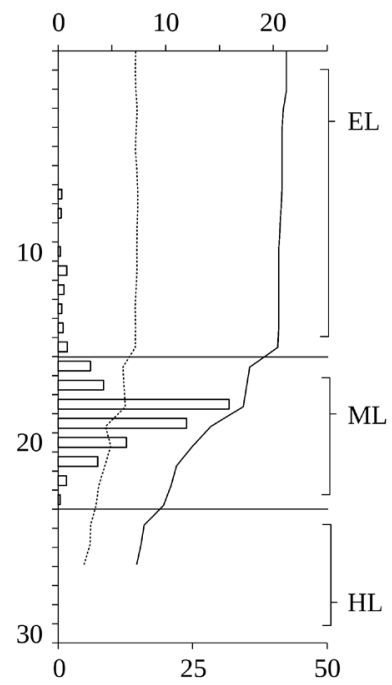

D

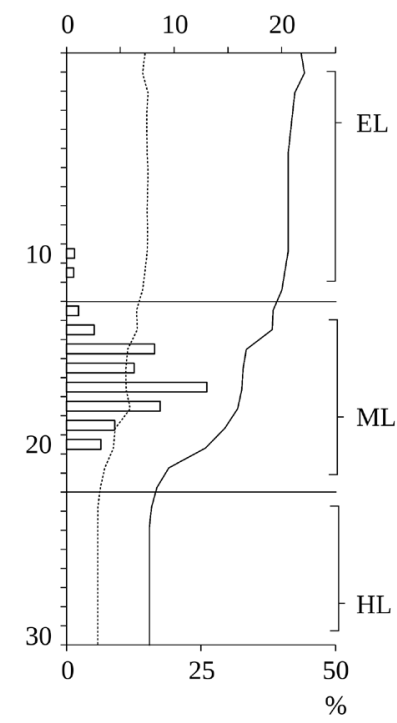

Fig. 1. Vertical distribution of fish at dusk (A), in the night (B), at dawn (C), during the daytime (D) in epilimnion (EL), metalimnion (ML), and hypolimnion $(\mathrm{HL})$. Upper X-axis: 1 - dissolved oxygen concentration, $\mathrm{mg} / \mathrm{L} ; 2$ - water temperature, ${ }^{\circ} \mathrm{C}$; lower $\mathrm{X}$-axis: relative fish population density, $\%$. 
Synchaeta pectinata Ehrenberg, 1832), four species of Copepoda (Cyclops abyssorum Sars, 1863; Diacyclops bicuspidatus (Claus, 1857); Acanthodiaptomus denticornis Wierzejski, 1887; Arctodiaptomus (Rhabdodiaptomus) bacillifer (Koelbel, 1885)), and three species of Cladocera (Daphnia hyalina; Diaphanosoma lacustris Kořinek, 1981; Leydigia leydigii (Schödler, 1863)). The number of species per sample varied insignificantly during the day, with the greatest change in $\mathrm{ML}$ and $\mathrm{HL}(\mathrm{Cv}=22.8$ and 22.0, respectively), the lowest, in EL $(C v=9.1)$ (Table 2). During the day and at sunset, the maximum number of species was found in $E L$, at night, in $E L$ and $M L$, at dawn, in $\mathrm{ML}$ and $\mathrm{HL}$. In EL, rotifers were always presented by the greatest number of species; in ML, they prevailed at sunset and at night, during the day the proportion of species of all taxonomic groups was the same, and rotifers and copepods prevailed at sunrise. In HL, during the day and at sunrise, Rotifera also dominated by the species number, at sunset, these were Rotifera and Copepoda, at night, the proportion of species of all groups was equal.

The highest abundance of ZP at sunset and at night was observed in $\mathrm{HL}$; during the day, the differences were insignificant, however, the lowest abundance was recorded in the ML, at dawn, in the $\mathrm{HL}$ (Table 2). The minimum range of abundance fluctuation during the day was observed in EL (on average, 1.2 times; $C v=16.4$ ), the maximum, in $\mathrm{HL}$ (on average, 1.8 times; $C v=31.5$ ), all noticeable changes occurred at sunset and at night, when population density increased in $\mathrm{ML}$ and $\mathrm{HL}$, but decreased in EL. Copepoda brought the most of ZP in $E L$, replaced by Cladocera only at sunrise. The latter prevailed in $\mathrm{ML}$ at sunset and at night, in $\mathrm{HL}$, during the entire observation period (Table 2). Keratella quadrata (except for the daytime in $\mathrm{HL}$ ) and Daphnia hyalina (except for EL during the daytime, at sunset, and at dawn) were the dominant species in all layers of the water column during the day; in $\mathrm{HL}$, their share in the total abundance was the largest (Table 3). Diaphanosoma lacustris dominated during the day in $\mathrm{EL}$, at night and at dawn in $\mathrm{ML}$, at dusk and dawn in $\mathrm{HL}$; its largest share in the total number of ZP was observed in EL. Calanoida nauplii were dominants in $\mathrm{EL}$, as well as in ML during the day and at dawn. The smallest similarity between the dominant species in $E L$ and $M L$ was recorded at sunset $(21.7 \%)$, during the rest of the day, it varied within $32.9-44.6 \%$. The minimum similarity of dominants was also noted during the day between the ML and $\mathrm{HL}(29.2 \%)$, the maximum, at sunset $(56.0 \%)$, at the rest of the time, it was $43.3 \%$ and $48.4 \%$. During the day, the dominant species common to the EL and HL layers were absent; however, the similarity increased up to $33.6 \%$ at sunset; during the rest of the day, it was $16.2 \%$ (at night) and $23.7 \%$ (at sunrise).
The highest ZP biomass during the day was recorded in HL, the lowest, in EL (Table 2). Fluctuations of biomass in EL were insignificant (on average, 1.1 times; $C v=9.8$ ), in $M L$ they were more pronounced (on average, 1.6 times; $C v=33.6$ ), reaching maximum in $\mathrm{HL}$ (on average, 2 times; $\mathrm{CV}=42.7$ ). In $\mathrm{ML}$ and $\mathrm{HL}$, an increase in biomass was observed at sunset and at night due to crustaceans, and the minimum values were noted during the day. Cladocera prevailed, their biomass decreased during the day in the entire water column, the maximum values were recorded in $\mathrm{EL}$ at sunset and dawn, in $\mathrm{ML}$ and $\mathrm{HL}$, at night (Table 2). The highest biomass of Copepoda in EL was recorded during the day, in $\mathrm{ML}$, at dawn, in $\mathrm{HL}$, at night; the lowest values were observed in $\mathrm{EL}$ at dawn, in $\mathrm{ML}$ and $\mathrm{HL}$, during the day. In all layers and at any time of the day, Daphnia hyalina dominated, its largest share was always characteristic for $\mathrm{ML}$ and $\mathrm{HL}$, the lowest share, in EL, especially during the day (Table 3). Diaphanosoma lacustris dominated only in EL (except for sunset), with the largest proportion observed during the day. Copepoda dominants were presented by Arctodiaptomus bacillifer (day and night in EL), as well as by Cyclops abyssorum (during the day in EL and ML, at dawn, in $\mathrm{ML}$ ). Since Daphnia hyalina was one of the dominant species in terms of biomass in almost all samples, the indices of the similarity of dominants between different water layers were high (63.0-86.6\%). However, in the daytime, due to a significant decrease in the proportion of $D$. hyalina in $\mathrm{EL}$, the index of similarity with $\mathrm{ML}$ was $24.7 \%$, with $\mathrm{HL}, 13.9 \%$.

The maximum AIM of ZP organisms during the day was observed in $\mathrm{HL}$, where the lowest values were noted during the daytime, the highest, at dawn (Fig. 2A). In ML, the minimum values were recorded during the day and at dawn, the maximum, at sunset. In EL, the variation of this indicator was low $(C V=14.1)$, comparing to $M L(C V=27.4)$ and $\mathrm{HL}(\mathrm{Cv}=23.7)$, the smallest value was noted at sunrise. Significant fluctuations in the AIM of the main dominant species, $D$. hyalina, were found in EL $(C v=50.3)$, where it decreased during the day and at night, and increased at dusk and dawn (Fig. 2B). In $\mathrm{HL}$, in the period from daytime to dawn, AIM of Daphnia increased $(C V=36.4)$, reaching at dawn higher values than in other layers. In the ML, the AIM of Daphnia varied insignificantly $(C v=18.1)$ with a maximum at sunset and at night, and a minimum in the daytime and at dawn. AIM of Diaphanosoma lacustris in EL was also characterized by a high degree of variation $(C v=92.2)$; during the daytime, the highest value was noted, then it sharply decreased to lower values than in other layers (Fig. 2C). In ML and $\mathrm{HL}$, the individual weight of $D$. lacustris varied to a lesser extent ( $C v=39.6$ and 23.6, respectively); in $\mathrm{HL}$ it was lower; there were no differences only at night. AIM of Cyclops abyssorum also varied to the 
Table 2. Number of species, abundance, biomass, and proportion of taxonomic groups of zooplankton in epilimnion (EL), metalimnion (ML), and hypolimnion (GL).

\begin{tabular}{|c|c|c|c|c|c|c|c|c|c|c|}
\hline \multirow{2}{*}{$\begin{array}{l}\text { Taxonomic } \\
\text { group }\end{array}$} & \multirow{2}{*}{$\begin{array}{l}\text { Light } \\
\text { conditions }\end{array}$} & \multicolumn{3}{|c|}{ Number of species } & \multicolumn{3}{|c|}{$\begin{array}{l}\text { Abundance, } \\
10^{3} \text { ind } . / \mathrm{m}^{3}\end{array}$} & \multicolumn{3}{|c|}{ Biomass, $\mathrm{mg} / \mathrm{m}^{3}$} \\
\hline & & $\mathrm{EL}$ & $M L$ & $\mathrm{HL}$ & EL & $M L$ & $\mathrm{HL}$ & EL & $M L$ & $\mathrm{HL}$ \\
\hline \multirow{4}{*}{ Rotifera, \% } & Dusk & 50.0 & 42.9 & 37.5 & 26.8 & 27.3 & 26.5 & 1.0 & 0.3 & 0.3 \\
\hline & Night & 44.4 & 44.4 & 33.3 & 17.0 & 24.1 & 20.3 & 0.7 & 0.4 & 0.2 \\
\hline & Dawn & 55.6 & 40.0 & 40.0 & 25.7 & 28.8 & 17.0 & 1.3 & 0.6 & 0.3 \\
\hline & Daytime & 50.0 & 33.3 & 50.0 & 31.2 & 15.2 & 8.3 & 1.1 & 0.3 & 0.1 \\
\hline \multirow{4}{*}{$\begin{array}{c}\text { Copepoda, } \\
\%\end{array}$} & Dusk & 30.0 & 28.6 & 37.5 & 50.9 & 30.4 & 19.4 & 17.0 & 12.1 & 8.1 \\
\hline & Night & 33.3 & 33.3 & 33.3 & 43.1 & 33.9 & 30.6 & 25.9 & 7.4 & 13.9 \\
\hline & Dawn & 22.2 & 40.0 & 30.0 & 32.9 & 40.8 & 30.4 & 12.9 & 21.5 & 11.7 \\
\hline & Daytime & 25.0 & 33.3 & 33.3 & 44.6 & 49.2 & 23.9 & 40.0 & 15.0 & 14.4 \\
\hline \multirow{4}{*}{$\begin{array}{c}\text { Cladocera } \\
\%\end{array}$} & Dusk & 20.0 & 28.6 & 25.0 & 22.3 & 42.3 & 54.1 & 82.0 & 87.6 & 91.6 \\
\hline & Night & 22.2 & 22.2 & 33.3 & 39.9 & 42.0 & 49.1 & 73.3 & 92.3 & 85.9 \\
\hline & Dawn & 22.2 & 20.0 & 30.0 & 41.4 & 30.4 & 52.6 & 85.8 & 77.9 & 88.0 \\
\hline & Daytime & 25.0 & 33.3 & 33.3 & 24.2 & 35.6 & 67.8 & 58.8 & 84.6 & 85.5 \\
\hline \multirow{4}{*}{ Total } & Dusk & 10 & 7 & 8 & 23.9 & 19.4 & 30.3 & 586.1 & 1244.3 & 2057.5 \\
\hline & Night & 9 & 9 & 6 & 18.2 & 30.8 & 41.6 & 465.2 & 1684.7 & 3160.6 \\
\hline & Dawn & 9 & 10 & 10 & 27.5 & 27.8 & 20.7 & 516.3 & 1034.2 & 1723.8 \\
\hline & Daytime & 8 & 6 & 7 & 24.0 & 19.9 & 24.2 & 500.4 & 744.9 & 1109.5 \\
\hline
\end{tabular}

greatest extent in EL $(C v=79.8)$, comparing to $\mathrm{ML}$ $(C v=32.9)$ and $\mathrm{HL}(\mathrm{Cv}=47.9)$; its maximum values during the day exceeded those in $\mathrm{ML}$ and $\mathrm{HL}$ (Fig. 2D). At sunset and at night, the individual mass of $C$. abyssorum decreased in EL, at sunrise, it slightly increased, but was lower than that in $\mathrm{ML}$ and $\mathrm{HL}$, where the highest values were found at sunrise. AIM of Arctodiaptomus bacillifer in EL also had a greater degree of variation $(C v=57.1)$ than in $\mathrm{ML}(C v=18.6)$ and in $\mathrm{HL}(C v=34.1)$ with a maximum during the day and a minimum at sunset (Fig. $2 \mathrm{E}$ ). In the ML, the highest AIM of $A$. bacillifer was recorded at sunset; it decreased at night, and increased again at sunrise. In $\mathrm{HL}$, the maximum was observed at night; during the rest of the time, the differences were insignificant, with a minimum observed at sunset. AIM of Copepo- da juveniles was characterized by minimal variation in $E L(C v=20.6)$, it was slightly higher in $M L$ and $\mathrm{HL}(\mathrm{CV}=36.8$ and 36.5 , respectively). The individual mass of nauplii and copepodites decreased at sunset in $\mathrm{EL}$ and $\mathrm{HL}$, at sunrise and at night in $\mathrm{ML}$, but increased at sunset in $\mathrm{ML}$, at night in $\mathrm{EL}$ and $\mathrm{HL}$ and at sunrise in $\mathrm{HL}$ (Fig. $2 F$ ).

The average density of the spatial distribution of fish, calculated over the entire water column, varied during the day. The maximum value was recorded at night, the minimum, during the day, when the density decreased by 18 times, probably because of horizontal migrations to adjacent parts of the reservoir (Table 4). The fish preferred ML, where $89-100 \%$ of the population kept at different times of the day. At sunset, the maximum fish distribution density was found 
A

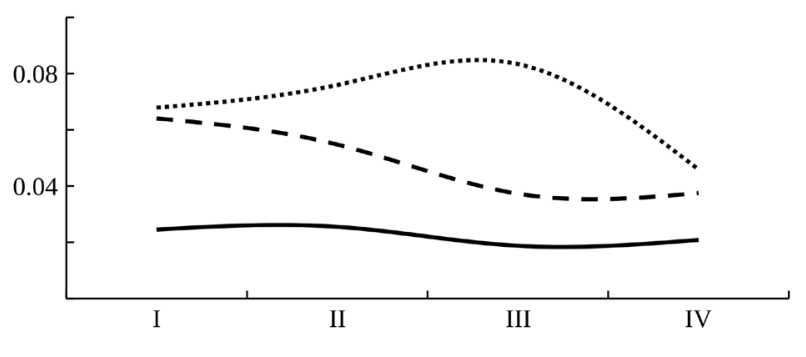

C

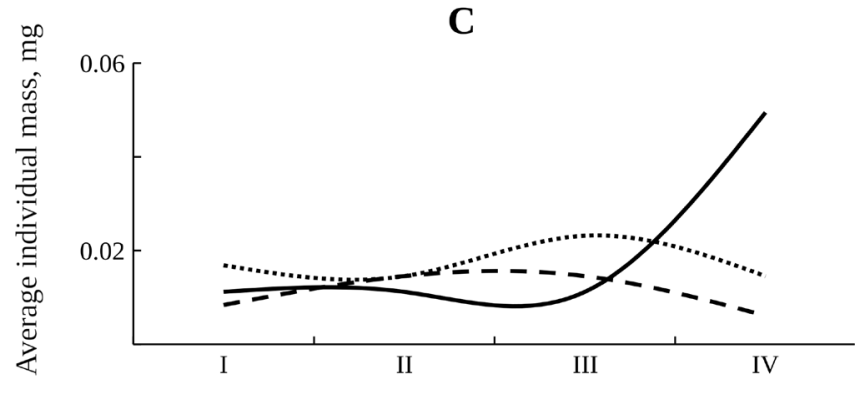

$\mathbf{E}$

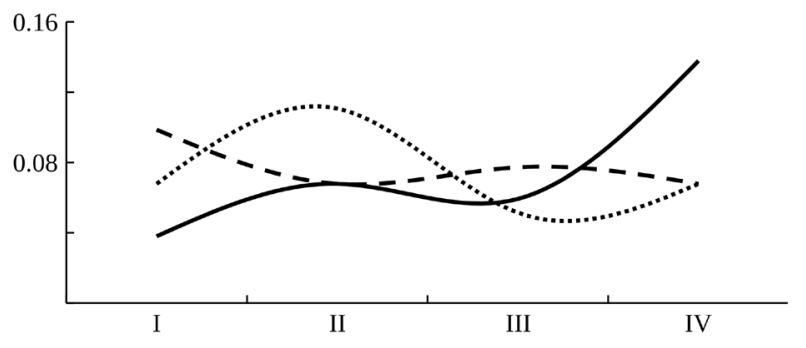

B

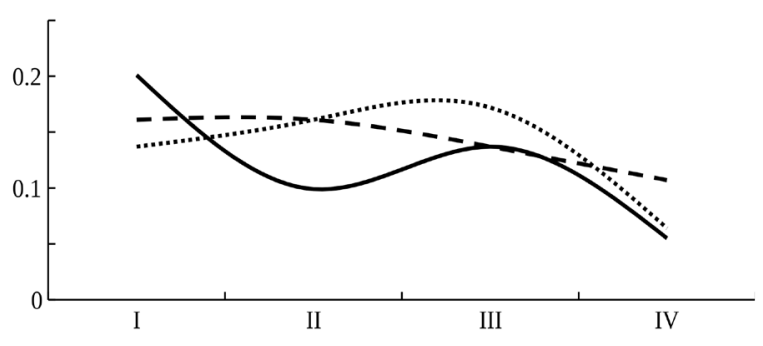

D
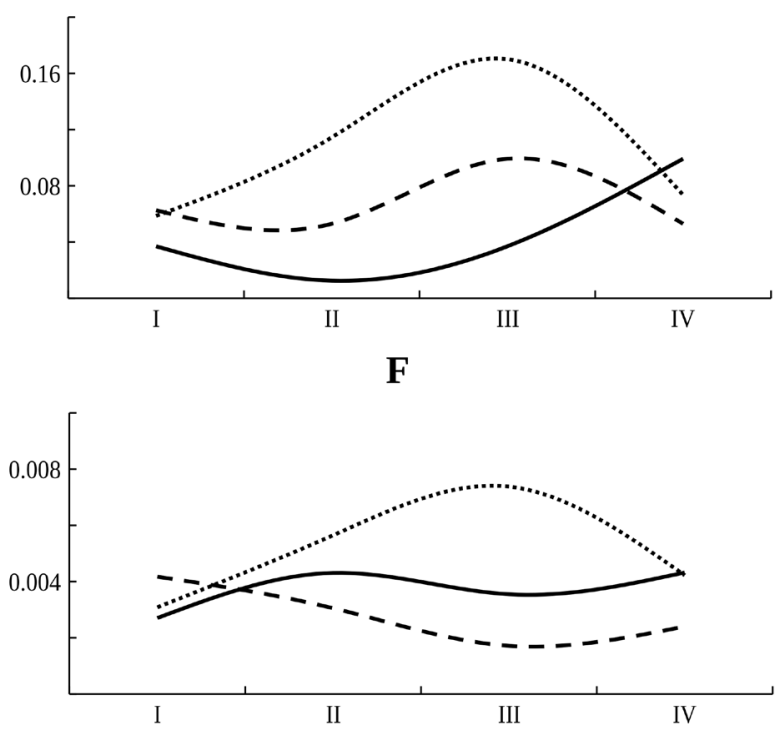

EL $\quad-$ - ML $\quad \cdots \cdots \cdots \cdot$ HL

Fig. 2. Average individual mass of key zooplankton organisms: A - all the species; B - Daphnia hyalina, C - Diaphanosoma lacustris, D - Cyclops abyssorum, E - Arctodiaptomus bacillifer, $\boldsymbol{F}$ - juvenile Copepoda at dusk (I), in the night (II), at dawn (III), during the daytime (IV) in epilimnion (EL), metalimnion (ML), and hypolimnion (HL).

at an 18-m depth, where the water temperature was $15.4{ }^{\circ} \mathrm{C}$; fish was absent in EL and HL (Fig. 1A). At night, the distribution of fish within the ML became more uniform, when the maximum density of their distribution was observed at a 19-m depth, where the water temperature was $11.6{ }^{\circ} \mathrm{C}$. Less than $1 \%$ of the fish was recorded in the lower margin of EL, directly at the border with the ML; $10 \%$ of the fish descended to $\mathrm{HL}$, where it was evenly distributed from the boundary with the ML to the bottom, despite the low oxygen content of 3.0-3.1 $\mathrm{mg} / \mathrm{L}$ at a temperature of $6.9^{\circ} \mathrm{C}$ (Fig. 1B). At dawn, fish were absent in the $\mathrm{HL}$ and were distributed over the entire $\mathrm{ML}$ layer, forming a maximum density at an 18-m depth at a temperature of $17.2{ }^{\circ} \mathrm{C}$. In the lower and middle layers of EL, where the temperature reached $20.8{ }^{\circ} \mathrm{C}, 7 \%$ of the fish ascended (Fig. 1C). During the day, about 95\% of the fish was concentrated in the $\mathrm{ML}$, the maximum was observed at a 17-m depth at a temperature of $16.3{ }^{\circ} \mathrm{C}$. Less than $1 \%$ of fish were recorded in $\mathrm{HL}$ and less than $5 \%$, in EL (Fig. 1D).

\section{Discussion}

Studies performed in July 2019 evidenced on uncharacteristic vertical distribution of zooplankton for Lake Sevan during the day. First, attention is drawn to the minimum values of biomass in EL with maximum values in $\mathrm{HL}$, as well as relatively low indices of the total ZP abundance. At the same time, there were no abiotic factors responsible such a distribution: the water temperature and the content of dissolved oxygen in $\mathrm{HL}$ did not correspond to the optimal conditions for the ZP development.

The influence of fish, which vertical distribution was also characterized by a number of atypical features, may be one of the reasons for the specific distribution of ZP; in many respects, our results did not agree with the previous data on Lake Sevan. Thus, it has been previously reported that whitefish prefer HL (Poddubny and Malinin, 1988) and leave it only if the oxygen concentration decreases down to $1-5 \mathrm{mg} / \mathrm{L}$ (Malinin et al., 1984). According to our observations, regardless of the time of day, most of whitefish keep in $M L$, while 
Table 3. Composition and proportion of zooplankton species dominating by abundance and biomass in epilimnion (EL), metalimnion (ML), and hypolimnion (GL).

\begin{tabular}{|c|c|c|c|c|c|c|c|c|c|c|c|c|}
\hline \multirow{2}{*}{ Taxon } & \multicolumn{3}{|c|}{ Dusk } & \multicolumn{3}{|c|}{ Night } & \multicolumn{3}{|c|}{ Dawn } & \multicolumn{3}{|c|}{ Daytime } \\
\hline & EL & ML & $\mathrm{HL}$ & EL & ML & $\mathrm{HL}$ & EL & ML & $\mathrm{HL}$ & EL & $\mathrm{ML}$ & $\mathrm{HL}$ \\
\hline & \multicolumn{12}{|c|}{ Share by abundance, $\%$} \\
\hline $\begin{array}{l}\text { Keratella } \\
\text { quadrata }\end{array}$ & 23.2 & 21.7 & 23.7 & 15.0 & 20.4 & 18.2 & 22.2 & 24.8 & 12.9 & 24.2 & 14.0 & - \\
\hline $\begin{array}{l}\text { Daphnia } \\
\text { hyalina }\end{array}$ & - & 34.3 & 44.0 & 16.2 & 30.2 & 39.5 & - & 20.0 & 40.9 & - & 29.2 & 58.7 \\
\hline $\begin{array}{c}\text { Diaphanosoma } \\
\text { lacustris }\end{array}$ & 13.0 & - & 10.2 & 23.7 & 11.8 & - & 32.3 & 10.4 & 10.8 & 18.9 & - & - \\
\hline Nauplii of Calanoida & 19.5 & - & - & 16.2 & - & - & 17.2 & 12.0 & - & 18.9 & 22.9 & - \\
\hline \multirow[t]{2}{*}{ Nauplii of Cyclopoida } & 14.9 & - & - & - & - & - & - & - & - & - & - & - \\
\hline & \multicolumn{12}{|c|}{ Share by biomass, $\%$} \\
\hline $\begin{array}{l}\text { Daphnia } \\
\text { hyalina }\end{array}$ & 76.1 & 86.6 & 89.0 & 63.0 & 89.1 & 84.1 & 66.7 & 73.8 & 84.6 & 13.9 & 83.6 & 82.6 \\
\hline $\begin{array}{c}\text { Diaphanosoma } \\
\text { lacustris }\end{array}$ & - & - & - & 10.4 & - & - & 19.3 & - & - & 44.9 & - & - \\
\hline $\begin{array}{l}\text { Cyclops } \\
\text { abyssorum }\end{array}$ & - & - & - & - & - & - & - & 13.4 & - & 14.4 & 10.8 & - \\
\hline $\begin{array}{c}\text { Arctodiaptomus } \\
\text { bacillifer }\end{array}$ & - & - & - & 13.3 & - & - & - & - & - & 17.5 & - & - \\
\hline
\end{tabular}

Table 4. Absolute spatial population density $(D)$ and relative abundance $(N)$ of fish in epilimnion (EL), metalimnion (ML), and hypolimnion (GL) and in the entire water column at different light conditions.

\begin{tabular}{|c|c|c|c|c|c|c|c|c|}
\hline \multirow{2}{*}{$\begin{array}{l}\text { Water } \\
\text { layer }\end{array}$} & \multicolumn{2}{|c|}{ Dusk } & \multicolumn{2}{|c|}{ Night } & \multicolumn{2}{|c|}{ Dawn } & \multicolumn{2}{|c|}{ Daytime } \\
\hline & $\begin{array}{c}D, \text { ind. } / 10^{6} \\
\mathrm{~m}^{3}\end{array}$ & $N, \%$ & $D$, ind. m $^{3} / 10^{6}$ & $N, \%$ & $\begin{array}{c}D, \text { ind. } . / 10^{6} \\
\mathrm{~m}^{3}\end{array}$ & $N, \%$ & 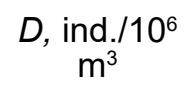 & $N, \%$ \\
\hline EL & 0 & 0 & 90.9 & 0.8 & 552.6 & 7.0 & 30.8 & 4.3 \\
\hline$M L$ & 1481.5 & 100 & 10091.4 & 89.2 & 7351.9 & 93.0 & 678.8 & 94.9 \\
\hline $\mathrm{HL}$ & 0 & 0 & 1134.3 & 10.0 & 0 & 0 & 5.5 & 0.8 \\
\hline $\begin{array}{l}\text { Entire } \\
\text { water } \\
\text { column }\end{array}$ & 740.7 & - & 5130.7 & - & 3765.8 & - & 279.8 & - \\
\hline
\end{tabular}


at night up to $10 \%$ of them descend to $\mathrm{HL}$, despite the low oxygen content in this layer (3.0-3.1 mg/L).

It has been also indicated that whitefish in Lake Sevan perform DVM, rising at night towards surface, when presumably following the food objects (Poddubny and Malinin, 1988). On the contrary, our observations evidence that at nighttime about $10 \%$ of the fish descends from $\mathrm{ML}$ to $\mathrm{HL}$, and some fish ascent from $M L$ to $E L(7 \%)$, where they are recorded at dawn (Figs. 1B, 1C).

The preferred water temperatures, which may be tracked by the depth of maximum fish density, also go beyond the ranges indicated earlier, i.e. $4-9{ }^{\circ} \mathrm{C}$ in Maly Sevan and $5-7^{\circ} \mathrm{C}$ in Bolshoy Sevan (Poddubny and Malinin, 1988). In our study, the water temperature, preferred by most of the fish, changes during the day and does not fall into these ranges, when the whitefish prefers the coldest waters $\left(11.6^{\circ} \mathrm{C}\right)$ at night, and the warmest $\left(17.2{ }^{\circ} \mathrm{C}\right)$ - at dawn, when, in turn, some fish ascend to EL, reaching a 7-m depth and a temperature of $20.8^{\circ} \mathrm{C}$ (Fig. 1).

At the same time, the observed pattern of the whitefish distribution may be explained by the concept of choosing the energetically optimal environmental temperature under stratification conditions, proposed by a number of authors. At low temperatures in $\mathrm{HL}$, metabolic processes slow down, which affects not only the duration of food digestion, but also the energy requirements of fish in general (Krogius, 1974; Poddubny and Malinin, 1988). Consequently, in the 1980s, the whitefish chose the cold-water $\mathrm{HL}$, probably due to the lack of food resources, since its abundance in those years was much higher than nowadays (Gabrielyan, 2010).

Currently, only a small proportion of whitefish migrate to the HL, and only at night, most likely, to slow down metabolism and to conserve energy. The low oxygen content in the HL does not limit these migrations, since the oxygen demand also decrease, probably, as a result of the slowing down of metabolic processes. At night, whitefish practically does not feed (Poddubny and Malinin, 1988), which may explain the high abundance of $\mathrm{ZP}$ in $\mathrm{HL}$. The ascend of a part of the fish school from ML to EL, observed at dawn, is probably also caused by ceasing of the feeding on ZP in the dark and due to a significant increase in the intensity of feeding in the morning. Presumably, at sunset, upon reaching the level of illumination of the water column, similar to that during dawn, the feeding intensity of whitefish increases as well, accompanied by partial migration to the EL, which has not been recorded in this study. A similar behavior was noted in the European vendace (Coregonus albula (Linnaeus, 1758)) in Lake Pleshcheyevo (Yaroslavl Region, Russia), based on the results of earlier original observations (Poddubny and Malinin, 1988).

Analysis of the spatiotemporal changes in fish population density in EL shows that during their maxi- mum density at dawn (Table 4), some ZP parameters were higher than during the absence of fish at sunset (total abundance of ZP, Cladocera abundance, the abundance and biomass of Diaphanosoma lacustris and Arctodiaptomus bacillifer). At the same time, at the highest fish density, a decrease in the abundance and biomass of Copepoda, biomass of Cladocera, total biomass of ZP, biomass and average individual mass of Daphnia hyalina have been noted (Table 2, Fig. 2). In ML, the abundance and biomass of main taxonomic groups of ZP, D. hyalina, and Diaphanosoma lacustris, as well as their AIM at the maximum fish density was higher than at the minimum (Table 2, Fig. 2). In HL, at the highest fish density, the highest abundance and biomass of ZP and dominant crustaceans were also found, and AIM of Daphnia hyalina, Diaphanosoma lacustris, and Cyclops abyssorum in this period was lower only when comparing to that at dawn (Table 2, Fig. 2). Consequently, only in EL, where most of the time the fish density and quantitative characteristics of ZP were lower than in other layers, a number of changes in the quantitative composition of invertebrates were observed. The latter are justifiably explained by the influence of fish nutrition in a number of publications (Hansson et al., 2007; Luecke et al., 1990; Mehner, 2000). However, in general, no noticeable effect on the ZP of spatiotemporal changes in fish density was revealed in the water column.

It is possible that the fish density increased due to their migration to the layers, where the abundance and biomass of the ZP increased, primarily of the dominant crustaceans, due to their daily migrations. It is known that crustaceans prefer deeper layers during the day and migrate to the upper layers at night, avoiding predators (Field and Prepas, 1997; Ringelberg, 2010; Stich, 1989). However, despite the most pronounced variation in the abundance and biomass of $\mathrm{ZP}$ in $\mathrm{HL}$ at the maximum at sunset and at night, we can state that during the period of our observations there were no clearly pronounced vertical migrations of the dominant crustacean species; their abundance, biomass, and the average individual mass changed simultaneously in all layers of water, regardless of the time of day or fluctuations in fish density.

Generally, this picture is not entirely consistent with most of the literature data, which indicate the persistence of diurnal migrations even in fishless mountain water bodies (Williamson et al., 2001). The absence of DVM in planktonic animals was recorded during hypoxia in $\mathrm{HL}$, when most animals were found in EL (Doubek et al., 2018). In Lacamas Lake (USA), no DVM of zooplankton were recorded, but some taxa kept in layers with pronounced hypoxia (Nolan et al., 2019). On the other hand, it has been shown that certain species and groups of planktonic animals in different water bodies may have different characteris- 
tics of DVM (Gladyshev, 1990), being both migrants and non-migrants. Some species can migrate within a water layer with certain temperature, for example, as Diaphanosoma mongolianum does within EL in Lake Pleshcheyevo (Zhdanova, 2018).

In Lake Sevan, relatively large $(0.8-1.6 \mathrm{~mm})$ Daphnia hyalina preferred $\mathrm{HL}$ and $\mathrm{ML}$, and smaller (0.8-1.6 mm) Diaphanosoma lacustris was more often concentrated in EL (Fig. 2, Table 3). The confinement of species to certain layers of the water column was noted earlier in other water bodies (Karpowicz et al., 2020). In lakes Glubokoe (Moscow Region, Russia) and Pleshcheyevo (Yaroslavl Region, Russia), Daphnia cristata is confined to $\mathrm{HL}, D$. galeata and $D$. hyalina, to ML, Diaphanosoma mongolianum and D. brachyurum, to EL (Stolbunova, 2006; Zhdanova, 2018; Zhdanova and Lazareva, 2009). In the water bodies of the canyon type in Czech Republic, Daphnia longispina and its hybrids more often dominated in ML and HL (Seda et al., 2007a). For D. galeata, genetically differentiated sub-populations have been identified, which do not leave the HL (Seda et al., 2007b).

Significant differences in the size of $D$. hyalina and Diaphanosoma lacustris precondition different filtration rates and food preferences of these species. It is known that the presence of fish stimulates the development of microscopic filter-feeders (Korovchinsky, 2004). Consequently, in Lake Sevan, the presence of whitefish may positively affect the survival and reproduction of small-sized Diaphanosoma. These relatively small zooplankters are less susceptible to being grazed by fish, while the relatively large Daphnia are more vulnerable.

The changes in ZP may be caused by the horizontal transfer of organisms by the water currents (Armengol et al., 2012). In addition, the low quantitative characteristics of invertebrates in EL may be associated with the fact that the main share of potential fish food was observed here during the recorded morning and supposed evening ascent from the ML, as evidenced by the minimum AIM of ZP at this time. However, the greatest activity of fish in EL could occur during the daytime, as evidenced by the minimum biomass, by the share of one of the preferred food objects, Daphnia, in the total biomass and AIM, as well as by the absence of common dominant species in the EL and HL. Nevertheless, the fact of daytime activity of fish in EL has not been recorded by hydroacoustic equipment; to confirm or refute this, continuous surveys are required.

The fish descended to $\mathrm{HL}$ only at night, despite the low oxygen content, which was not critical for invertebrates either. Some authors report that planktonic invertebrates, in particular, representatives of the genera Daphnia and Bosmina, can inhabit the lower layers of the water column even at low oxygen content and use them as refugia from predators, even if the food source there is limited (Hanazato, 1992, 1995; Sell, 1998; Vanderploeg et al., 2009). Data on chlorophyll $a$, obtained only in the daytime unfortunately, also testify to the rich food base of the ZP in $\mathrm{HL}$. Thus, in EL, its average amount was $0.6 \mu \mathrm{g} / \mathrm{L}$, in $\mathrm{ML}, 0.4 \mu \mathrm{g} / \mathrm{L}$, and in $\mathrm{HL}, 1.1 \mu \mathrm{g} / \mathrm{L}$. A sufficient food supply for $\mathrm{ZP}$ in $\mathrm{HL}$ is also supported by the quantitative composition of BP and HNF (Table 1). The average daily number and biomass of bacteria in $\mathrm{HL}$ were higher than that in EL and ML. It was found that the biomass of BP decreased as the abundance and biomass of HNF increased $\left(r_{s}=-0.63\right.$ and -0.62 , $p<0.05$ ); the average abundance and biomass of latter were lower in $\mathrm{HL}$ than in EL and ML. Probably, this was due to the control of their number by the $\mathrm{ZP}$, which was indicated by the positive correlation between the biomass of invertebrates and the abundance of $\mathrm{BP}\left(r_{s}=0.58, p<0.05\right)$.

We assume that the processes of horizontal transfer of ZP by currents and horizontal migrations of whitefish, which may help to explain some peculiarities of the dynamics of the observed characteristics, cannot cause directly such atypical features of the vertical distribution of the considered groups of aquatic organisms. Since these processes occur in a horizontal direction, organisms are not redistributed between EL, ML and HL. Horizontal transfer of water masses and horizontal migrations of fish played a certain role in the earlier stages of the reservoir's history, including the period of describing "typical" patterns of distribution of ZP and fish, but the role of horizontal transfer has not been studied.

Apparently, in this study, we observed the diurnal dynamics of rare patterns of the vertical distribution of whitefish and ZP, which were not described for Lake Sevan earlier. Possible reasons causing these patterns may be divided into two groups: (1) such changes did not occur during the periods of earlier observations, or (2) they did occur, but were not recorded. In the first case, the manifestation of new features of vertical distribution in two groups of aquatic organisms at once indicates changes in the ecosystem of the reservoir. They may be caused by a rise in the water level of the lake, significant fluctuations in the abundance of whitefish, changes in the species composition of zooplankton, phytoplankton blooms, as well as other phenomena occurring in Lake Sevan in recent decades (Krylov et al., 2019a, 2019b, 2021). It is also probable that the observed patterns are characteristic of ZP and whitefish from Lake Sevan, not recorded by earlier studies, since they appeared at a certain combination of events and lasted shortly. It should be noted that detailed comprehensive studies of the diurnal dynamics of the vertical distribution of aquatic organisms in this water body were carried out for the first time. Elucidation of the true reasons of the observed phenomenon requires further research. An increase in 
the sample size of the material collected according to the proposed method may bring statistically significant estimates of the studied characteristics during the water stratification in summer in Lake Sevan.

\section{Conclusions}

Information on the atypical distribution of whitefish in Lake Sevan obtained in the summer of 2019 forces us to take a fresh look at the role of hypolimnion in ecosystems of stratified water bodies. In the hypolimnion, maximal zooplankton biomass may be observed, while the planktivore periodically migrates to the hypolimnion despite unfavorable oxygen conditions and does not exploit the available food resource, but uses the environmental conditions optimal for body energetics.

Our results evidence that assessing generally accepted factors preconditioning the daily dynamics of the vertical distribution of zooplankton, namely, presence of DVM of zooplankton against the background of the DVM of the planktivorous fish, cannot provide an unambiguous explanation of the study results. The observed site of the lake is an open system, where a continuous exchange of water mass with the rest of the reservoir takes place. For this reason, the environmental hydrophysical parameters change; due to passive transfer, zooplankton community changes as well, this makes it difficult to distinguish such processes from the consequences of DVM or consumption by planktivore, since fish are able to migrate horizontally back and forth to adjacent areas of the reservoir. Probably, all these changes are not characterized by a pronounced daily cyclicity.

\section{Acknowledgments}

The authors are grateful to A.I. Tsvetkov (I.D. Papanin Institute for Biology of Inland Waters, Russian Academy of Sciences) for measuring and providing hydrophysical data (water temperature, concentration of oxygen content) and assistance in collecting hydrobiological material. Special thanks go to G.A. Gevorgyan (Scientific Center of Zoology and Hydroecology of the National Academy of Sciences of the Republic of Armenia) for data courtesy (chlorophyll concentration) in Lake Sevan during the study period.

\section{Funding}

The study was carried out within the state assignments nos. AAAA-A18-118012690106-7, AAAA-A18-118012690102-9 and AAAAA18118012690098-5.

\section{ORCID}

M.I. Malin (ID 0000-0001-5513-6405

S.M. Zhdanova (iD) 0000-0003-1094-2010

D.B. Kosolapov (iD $00000-0001-6854-0423$

I.P. Malina (iD 0000-0002-4257-2133

N.G. Kosolapova (iD 0000-0002-2044-160X
R.Z. Sabitova (iD) 0000-0002-1558-7380

A.V. Krylov (iD) $\underline{0000-0003-1371-7310}$

\section{References}

Armengol, X., Wurtsbaugh, W.A., Camacho, A., Miracle, M.R., 2012. Pseudo-diel vertical migration in zooplankton: a whole-lake ${ }^{15} \mathrm{~N}$ tracer experiment. Journal of Plankton Research 34 (11), 976-986. https://doi.org/10.1093/plankt/fbs058

Asatryan, V.L., Barseghyan, N.E., Vardanyan, T.V., Yepremyan, H.V., Hayrapetyan, A.O., Dallakyan, M.R., Gabrielyan, B.K., 2016. Analysis of the state of biocenoses that formed in shallow areas of Small Sevan (Armenia) during the period of lake's water level rise. Inland Water Biology 9, 1-7. https://doi. org/10.1134/S199508291601003X

Balushkina, E.B., Vinberg, G.G., 1979. Zavisimost' mezhdu massoi i dlinoi tela u planktonnykh zhivotnykh [Relationship between the weight and length of the body in planktonic animals]. In: Vinberg, G.G. (ed.), Obshchie osnovy izucheniia vodnykh ekosistem [General Principles of Research of Aquatic Ecoasystems]. Nauka, Leningrad, USSR, 169-172. (In Russian).

Brooks, J.L., Dodson, S., 1965. Predation, body size, and composition of plankton. Science 150 (3692), 28-35. https://doi.org/10.1126/ science. 150.3692 .28

Caron, D.A., 1983. Technique for enumeration of heterotrophic and phototrophic nanoplankton, using epifluorescence microscopy, and comparison with other procedures. Applied and Environmental Microbiology 46 (2), 491-498. https://doi. org/10.1128/AEM.46.2.491-498.1983

De Meester, L., Dawidowicz, P., Van Gool, E., Loose, C.J., 1999. Ecology and evolution of predator-induced behavior of zooplankton: depth selection behavior and diel vertical migration. In: Tollrian, R., Harvell, D.C. (eds.), The ecology and evolution of inducible defenses. Princeton University Press, Princeton, New Jersey, USA, 161-176.

Doubek, J.P., Campbell, K.L., Doubek, K.M., Hamre, K.D., Lofton, M.E., McClure, R.P., Ward, N.K., Carey, C.C., 2018. The effects of hypolimnetic anoxia on the diel vertical migration of freshwater crustacean zooplankton. Ecosphere 9 (7), e02332. https://doi.org/10.1002/ecs2.2332

Field, K.M., Prepas, E.E., 1997. Increased abundance and depth distribution of pelagic crustacean zooplankton during hypolimnetic oxygenation in 
a deep, eutrophic Alberta lake. Canadian Journal of Fisheries and Aquatic Sciences 54 (9), 21462156. https://doi.org/10.1139/f97-121

Fitzmaurice, P., 1979. Selective predation on Cladocera by brown trout Salmo trutta L. Journal of Fish Biology 15, 521-525. https://doi. org/10.1111/j.1095-8649.1979.tb03642.x

Gabrielyan, B.K., 2010. Ryby ozera Sevan [Fishes of Lake Sevan]. Gitutiun, Erevan, Armenia, 252 p.

Galbraith, M.G., 1967. Size-selective predation on Daphnia by rainbow trout and yellow perch. Transactions of the American fisheries Society 96, 1-10. https://doi.org/10.1577/15488659(1967)96[1:SPODBR]2.0.CO;2

Gerritsen, J., 1982. Behavioral response of Daphnia to rate of temperature change: Possible enhancement of vertical migration. Limnology and Oceanography 27 (2), 254-261. https://doi. org/10.4319/lo.1982.27.2.0254

Gladyshev, M.I., 1990. Sutochnaia dinamika vertikal'nogo raspredeleniia massovykh vidov zooplanktona $v$ Sydinskom zalive Krasnoiarskogo vodokhranilishcha [Diel dynamics of vertical distribution of key zooplankton species in Sydinskii Bay of Krasnoyarsk Reservoir]. Izvestiya Sibirskogo otdeleniya Akademii nauk SSSR. Seriya biologicheskikh nauk [Bulletin of the Siberian Branch of the Academy of Sciences of the USSR. Biological Sciences Series] 3, 78-85. (In Russian).

Gliwicz, Z.M., Rutkowska, A.E., Wojciechowska, J., 2000. Daphnia populations in three interconnected lakes with roach as the principal planktivore. Journal of Plankton Research 22 (8), 1539-1557. https://doi.org/10.1093/plankt/22.8.1539

Han, B-P., Straskraba, M., 1998. Modelling patterns of zooplankton diel vertical migration. Journal of Plankton Research 20 (8), 1463-1487. https://doi. org/10.1093/plankt/20.8.1463

Hanazato, T., 1992. Direct and indirect effects of lowoxygen layers on lake zooplankton communities. Archiv für Hydrobiologie, Beiheft Ergebnisse der Limnologie 35, 87-98.

Hanazato, T., 1995. Life history responses of two Daphnia species of different sizes against a fish kairomone. Japanese Journal of Limnology 56, 27-32.

Hansson, L-A., Nicolle, A., Brodersen, J., Romare, P., Nilsson, P.A., Brönmark, C., Skov, C., 2007.
Consequences of fish predation, migration, and juvenile ontogeny on zooplankton spring dynamics. Limnology and Oceanography 52 (2), 696-706. https://doi.org/10.4319/lo.2007.52.2.0696

Helland, I.P., Freyhof, J., Kasprzak, P., Mehner, T., 2007. Temperature sensitivity of vertical distributions of zooplankton and planktivorous fish in a stratified lake. Oecologia 151 (2), 322-330. https://doi.org/10.1007/s00442-006-0541-x

Karpowicz, M., Ejsmont-Karabin, J., Kozłowska, J., Feniova, I., Dzialowski, A.R., 2020. Zooplankton community responses to oxygen stress. Water 12 (3), 706. https://doi.org/10.3390/w12030706

Kiselev, I.A., 1980. Plankton morei i kontinental'nykh vodoemov. Raspredelenie, sezonnaia dinamika, pitanie i znachenie [Plankton of seas and continental waterbodies. Distribution, seasonal dynamics, feeding and significance]. Nauka, Leningrad, USSR, 440 p. (In Russian).

Korovchinskii, N.M., 2004. Vetvistousye rakoobraznye otriada Ctenopoda (morfologiya, sistematika, ekologiia, zoogeografiya) [Cladocerans of order Ctenopoda (morphology, systematics, ecology, zoogeography)]. KMK, Moscow, Russia, 410 p. (In Russian).

Krivopuskova, E.V., Masiutkina, E.A., Sokolov, A.V., Shibaeva, M.N., 2014. Kharakteristika sostava pishchi ryapushki (Coregonus albula) ozera Vishtynetskogo (Kaliningradskaia oblast') v sovremennykh usloviiakh [The characteristics of vendace (Coregonus albula) diet composition in Lake Vishtynetskoe (Kaliningrad Region) in modern conditions]. Izvestiia Kaliningradskogo gosudarstvennogo tekhnicheskogo universiteta [Bulletin of the Kaliningrad State Technical University] 32, 107-115. (In Russian).

Krivopuskova, E.V., Sokolov, A.V., 2018. Vliianie sezonnykh temperaturnykh izmenenii $v$ ozere Vishtynetskom (Kaliningradskaia oblast') na vertikal'noe raspredelenie ulovov evropeiskoi riapushki [Impact of the seasonal changes of the temperature in Lake Vishtynetskoe (Kaliningrad Region) on vertical pattern of vendace catches]. Vestnik molodezhnoi nauki [Bulletin of the Youth Science] 1 (13), 1-7. (In Russian).

Krogius, F.V., 1974. Znachenie vertikal'nykh migratsii $\mathrm{v}$ energeticheskom balanse molodi krasnoi oz. Dal'nego [The significance of the vertical migration in energetic balance of sockeye salmon juveniles in Lake Dal'nee]. Izvestiya TINRO [Transactions 
of the Pacific Research Institute of Fisheries and Oceanography] 90, 39-48. (In Russian).

Krylov, A.V., Akopian, S.A., Nikogosian, A.A., Hayrapetyan, A.O., 2010. Zooplankton ozera Sevan $i$ ego pritokov [Zooplankton of Lake Sevan and its tributaries]. In: Krylov, A.V. (ed.), Ekologiia ozera Sevan v period povysheniia ego urovnia. Rezul'taty issledovanii Rossiisko-Armianskoi biologicheskoi ekspeditsii po gidroekologicheskomu obsledovaniiu ozera Sevan (Armeniia) (2005-2009 gg.) [Ecology of Lake Sevan during the period of water level rise. The results of Russian-Armenian Biological expedition for hydroecological survey of Lake Sevan (Armenia) (2005-2009)]. Nauka Dagestan Scientific Center, Makhachkala, Russia, 168-200. (In Russian).

Krylov, A.V., Hayrapetyan, A.O., Kosolapov, D.B., Sakharova, E.G., Kosolapova, N.G. et al., 2021. Osobennosti izmenenii struktury planktona pelagiali gornogo ozera pri uvelichenii plotnosti ryb letom i osen'iu [Features of structural changes in the plankton community of an alpine lake with increasing fish density in summer and autumn]. Zoologicheskii zhurnal [Zoological Journal] 100 (2), 147-158. (In Russian). https://doi.org/10.31857/ S0044513420120053

Krylov, A.V., Hayrapetyan, A.O., Nikogosian, A.A., Bolotov, S.E., 2016. Vertikal'noe raspredelenie zooplanktona ozera Sevan [Vertical distribution of zooplankton in Lake Sevan]. In: Krylov, A.V. (ed.), Ozero Sevan. Ekologicheskoe sostoianie $v$ period izmeneniia urovnia vody [Lake Sevan. Ecological state during the period of water level change]. Filigran', Yaroslavl, Russia, 150-156. (In Russian)

Krylov, A.V., Hayrapetyan, A.O., Tsvetkov, A.I., Gerasimov, Yu.V., Malin, M.I., Gabrielyan, B.K., 2019a. Interannual changes in the quantitative parameters and structure of invertebrates in the littoral and pelagic zones of Lake Sevan (Armenia) with fluctuations in meteorological conditions and fish biomass. I. Summer zooplankton. Inland Water Biology 12, 298-305. https://doi.org/10.1134/ S1995082919030088

Krylov, A.V., Hayrapetyan, A.O., Tsvetkov, A.I., Gerasimov, Yu.V., Malin, M.I., Gabrielyan, B.K., $2019 \mathrm{~b}$. Interannual changes in the quantitative parameters and structure of invertebrates in the littoral and pelagic zones of Lake Sevan (Armenia) with fluctuations in meteorological conditions and fish biomass. II. Autumn zooplankton. Inland Water Biology 12, 409-417. https://doi.org/10.1134/ S199508291903009X
Lampert, W., 1989. The adaptive significance of diel vertical migration of zooplankton. Functional Ecology 3 (1), 21-27. https://doi. org/10.2307/2389671

Lampert, W., McCauley, E., Manly, B.F.J., 2003. Trade-offs in the vertical distribution of zooplankton: Ideal free distribution with costs? Proceedings of the Royal Society of London. Series B: Biological Sciences 270 (1516), 765-773. https://dx.doi. org/10.1098\%2Frspb.2002.2291

Larsson, P., Dodson, S.I., 1993. Chemical communication in planktonic animals. Archiv für Hydrobiologie 129 (2), 129-155. https://doi. org/10.1127/archiv-hydrobiol/129/1993/129

Loose, C.J., Dawidowicz, P., 1994. Trade-offs in diel vertical migration by zooplankton: The costs of predator avoidance. Ecology 75 (8), 2255-2263. https://doi.org/10.2307/1940881

Luecke, C., Vanni, M.J., Magnuson, J.J., Kitchell, J.F., Jacobson, P.T., 1990. Seasonal regulation of Daphnia populations by planktivorous fish: Implications for the spring clear-water phase. Limnology and Oceanography 35 (8), 1718-1733. https://doi.org/10.4319/lo.1990.35.8.1718

Malinin, L.K., Poddubnyi, A.G., Oganesian, R.O., Smolei, A.I., Yudanov, K.I., 1984. Plotnost' i prostranstvennoe raspredelenie ryb $\mathrm{v}$ ozere Sevan $v$ period letnego nagula [Population density and spatial distribution of the fish in Lake Sevan during the summer growing period]. Limnologiia gornykh vodoemov. Tezisy dokladov vsesoiuznogo soveshchaniia [Limnology of alpine waterbodies. Proceedings of All-Soviet-Union conference], Sevan, September 11-15, 1984 . Erevan, USSR, 150-151. (In Russian).

Mehner, T., 2000. Influence of spring warming on the predation rate of underyearling fish on Daphnia a deterministic simulation approach. Freshwater Biology 45 (2), 253-263. https://doi.org/10.1046/ j.1365-2427.2000.00551.x

Nikogosian, A.A., 1985. Izmeneniia v zooplanktone ozera Sevan v sviazi s ponizheniem ego urovnia [Changes in zooplankton of Lake Sevan due to water level decreasing]. Biological sciences $P h D$ thesis. Moscow, USSR, 21 p. (In Russian).

Nolan, S., Bollens, S.M., Rollwagen-Bollens, G., 2019. Diverse taxa of zooplankton inhabit hypoxic waters during both day and night in a temperate eutrophic lake. Journal of Plankton Research 41 (4), 431-447. https://doi.org/10.1093/plankt/fbz021 
Ohman, M.D., Frost, B.W., Cohen, E.B., 1983. Reverse diel vertical migration: An escape from invertebrate predators. Science 220 (4604), 1404-1407.

Poddubnyi, A.G., Malinin, L.K., 1988. Migratsii ryb vo vnutrennikh vodoemakh [Migrations of fish in inland waterbodies]. Agropromizdat, Moscow, USSR, 224 p. (In Russian).

Porter, K.G., Feig, Y.S., 1980. The use of DAPI for identifying and counting of aquatic microflora. Limnology and Oceanography 25 (5), 943-948. https://doi.org/10.4319/lo.1980.25.5.0943

Razlutskij, V.I., Feniova, I.Y., Ejsmont-Karabin, J., Palash, A.L., Tunowski, J., Sysova, E., Zilitinkevich, N.S., 2018. Impact of enhanced summer temperatures on the distribution and structure of zooplankton communities in the heated stratified lakes: Implications for climate change. Limnologica 73, 1-11. https://doi.org/10.1016/j.limno.2018.08.004

Rhode, S.C., Pawlowski, M., Tollrian, R., 2001. The impact of ultraviolet radiation on the vertical distribution of zooplankton of the genus Daphnia. Nature 412 (6842), 69-72. https://doi. org/10.1038/35083567

Ringelberg, J., 2010. Diel vertical migration of zooplankton in lakes and oceans: Causal explanations and adaptive significances. Springer, Dordrecht, Netherlands, 356 p. https://doi. org/10.1007/978-90-481-3093-1

Riv'er, I.K., 1975. Zooplankton i neiston [Zooplankton and neuston]. In: Mordukhai-Boltovskoi, F.D. (ed.), Metodika izucheniia biogeotsenozov vnutrennikh vodoemov [Method to study biogeocenoses of inland waterbodies]. Nauka, Moscow, USSR, 138157. (In Russian).

Rudyakov, lu.A., 1986. Dinamika vertikal'nogo raspredeleniia pelagicheskikh zhivotnykh [Dynamics of Vertical Distribution of Pelagic Animals]. Nauka, Moscow, USSR, 135 p. (In Russian).

Seda, J., Petrusek, A., Machacek, J., Smilauer, P., 2007a. Spatial distribution of the Daphnia longispina species complex and other planktonic crustaceans in the heterogeneous environment of canyon-shaped reservoirs. Journal of Plankton Research 29 (7), 619-628. https://doi.org/10.1093/ plankt/fbm044

Seda, J., Kolarova, K., Petrusek,A., Machacek, J., 2007b. Daphnia galeata in the deep hypolimnion: Spatial differentiation of a "typical epilimnetic" species. Hydrobiologia 594, 47-57. https://doi. org/10.1007/s10750-007-9075-4

Sell, A.F., 1998. Adaptation to oxygen deficiency: Contrasting patterns of haemoglobin synthesis in two coexisting Daphnia species. Comparative Biochemistry and Physiology Part A: Molecular \& Integrative Physiology 120, 119-125. https://doi. org/10.1016/S1095-6433(98)10019-3

Shapiro, J., Wright, D.I., 1984. Lake restoration by biomanipulation: Round Lake, Minnesota, the first two years. Freshwater Biology 14, 371-383. https:// doi.org/10.1111/j.1365-2427.1984.tb00161.x

Sih, A., Ziemba, R., Harding, K.C., 2000. New insights on how temporal variation in predation risk shapes prey behavior. Trends in Ecology and Evolution 15 (1), 3-4. https://doi.org/10.1016/ s0169-5347(99)01766-8

Simmonds, J., MacLennan, D., 2005. Fisheries acoustics: Theory and practice, second edition. Blackwell Science Ltd., Oxford, UK, 437 p. https:// doi.org/10.1002/9780470995303

Simonian, A.A., 1991. Zooplankton ozera Sevan [Zooplankton of Lake Sevan]. Academy of Sciences of Armenia Publishing House, Erevan, Armenia, 299 p. (In Russian).

Spaak, P., Hoekstra, J.R., 1997. Fish predation on a Daphnia hybrid species complex: A factor explaining species coexistence? Limnology and Oceanography 42 (4), 753-762. https://doi. org/10.4319/lo.1997.42.4.0753

Stich, H.B., 1989. Seasonal changes of diel vertical migration of crustacean plankton in Lake Constance. Archiv für Hydrobiologie. Supplementband. Monographische Beiträge 83 (3), 355-405.

Stolbunova, V.N., 2006. Zooplankton oz. Pleshcheevo [Zooplankton of Lake Pleshcheyevo]. Nauka, Moscow, Russia. 150 p. (In Russian).

Tartarotti, B., Cabrera, S., Psenner, R., Sommaruga, R., 1999. Survivorship of Cyclops abyssorum tatricus (Cyclopoida, Copepoda) and Boeckella gracilipes (Calanoida, Copepoda) under ambient levels of solar UVB radiation in two high-mountain lakes. Journal of Plankton Research 21 (3), 549-560. https://doi.org/10.1093/plankt/21.3.549

Vainshtein, B.A., 1976. Ob otsenke skhodstva mezhdu biotsenozami [About the similarity assessment of biocenoses]. In: Kamshilov, M.M. (ed.), Biologiya, morfologiya i sistematika vodnykh organizmov 
[Biology, morphology, and systematics of aquatic organisms]. Nauka, Leningrad, USSR, 156-164. (In Russian).

Vanderploeg, H.A., Ludsin, S.A., Cavaletto, J.F., Höök, T.O., Pothoven, S.A. et al., 2009. Hypoxic zones as habitat for zooplankton in Lake Erie: Refuges from predation or exclusion zones? Journal of Experimental Marine Biology and Ecology 381 Supplement, S108-S120. https://doi. org/10.1016/j.jembe.2009.07.015

Williamson, C.E., Olson, O.G., Lott, S.E., Walker, N.D., Engstrom, D.R., Hargreaves, B.R., 2001. Ultraviolet radiation and zooplankton community structure following deglaciation in Glacier Bay, Alaska. Ecology 82 (6), 1748-1760. https://doi.org/10.1890/00129658(2001)082[1748:URAZCS]2.0.CO;2

Williamson, C.E., Fischer, J.M, Bollens, S.M., Overholt, E.P., Breckenridge, J.K., 2011. Toward a more comprehensive theory of zooplankton diel vertical migration: Integrating ultraviolet radiation and water transparency into the biotic paradigm. Limnology and Oceanography 56 (5), 1603-1623. https://doi.org/10.4319/lo.2011.56.5.1603

Zhdanova, S.M., 2018. Diaphanosoma mongolianum Ueno, 1938 (Cladocera: Sididae) in Lakes of Yaroslavl Oblast (Russia). Inland Water Biology 11 (2), 154-152. https://doi.org/10.1134/ S1995082918020207

Zhdanova, S.M., Lazareva, V.I., 2009. Vidovoi sostav i prostranstvennoe raspredelenie letnego (iiul') zooplanktona ozera Glubokogo [Species composition and spatial distribution of the summer (July) zooplankton in Lake Glubokoe]. Trudy Gidrobiologicheskoi stantsii na Glubokom ozere [Transactions of Hydrobiological station at Lake Glubokoe] 10, KMK, Moscow, Russia, 51-66. (In Russian). 